\title{
Revista de Educação e Pesquisa em Contabilidade
}

Vol. 2, n. ${ }^{\circ} 2$

ISSN $1981-8610$

maio/ago 2008

Este novo número da Revista de Educação e Pesquisa em Contabilidade (REPeC) inaugura uma nova etapa na caminhada para consolidar a REPeC como mais um periódico de qualidade na área de Ciências Contábeis, ainda carente de veículos de divulgação científica em número suficiente para dar vasão a uma produção acadêmica, que começa a se apresentar como importante tanto em volume quanto na diversidade dos temas estudados, afinal contamos com 18 Programas de Mestrado e 3 Doutorados em Contabilidade, além dos vários grupos de pesquisa na graduação vinculados ao Programa de Bolsas de Iniciação Científica (PIBIC) do CNPQ, que também integram a base de construtores de divulgadores do conhecimento em contabilidade.

A REPeC estruturou o Comitê de Política Editorial atualmente formado pelos Professores Doutores Valcemiro Nossa (Fucape/ES); Carlos Renato Theophilo (Unimontes/MG); Marcelle Colares de Oliveira (Unifor/CE) e llse Maria Beuren (Furb/SC), grupo que tenho a honra de coordenar como Editor Científico. Também foi definido o Corpo Editorial Científico formado pelos Professores Doutores Edgard Bruno Cornachione JR (FEA/USP); Ernani Ott (Unisinos/RS); Jeronymo José Libonati (PPGCC/UFPE); Jorge Eduardo Scarpin (Furb/ $\mathrm{SC}$ ); Ivam Ricardo Peleias (Fecap/SP); Lauro Brito de Almeida (UFPR/PR); Lino Martins da Silva (UERJ/RJ); Maisa de Souza Ribeiro (FEA/USP-RP); Márcia Martins Mendes De Luca (UFC/CE); Mariomar de Sales Lima (Ufam/AM); Paulo Roberto Barbosa Lustosa (UnB-DF); Roberta Carvalho de Alencar (Fucape/ES); Romualdo Douglas Colauto (UFMG/ MG); Sônia Maria Silva Gomes (UFBA/BA); Leandro Cañibano (Universidad Autônoma de Madrid/Espanha) e Luís Lima Santos (Instituto Politécnico de Leiria/Portugal). Estamos alistando, agora, os consultores ad hoc, que ajudarão nos pareceres dos artigos e das resenhas submetidos.

Os artigos agora publicados abordam temas de auditoria contábil na perspectiva da prova pericial; discute, também, modelos para avaliação de ativos intangíveis, um tema que envolve desafios conceituais sempre relevantes para a contabilidade;oferece uma discussão sobre pregão eletrônico, a partir de um estudo que analisa a viabilidade de sua implantação e a repercussão para apuração nos resultados de processos licitatórios; debate os pareceres do Controle Externo, emitidos com ressalvas, sobre as prestações de contas de prefeituras municipais na perspectiva de se identificar cenários de aperfeiçoamento na gestão dos municípios; oferece uma oportunidade sempre bem- 
Vol. $2, \mathrm{n}^{\circ} 2$

ISSN $1981-8610$

maio/ago 2008

vinda de aprofundar os debates em torno do controle gerencial de universidades públicas, com um artigo que associa medidas de desempenho e evasão escolar. Por fim, temos uma resenha que destaca o pensamento do professor Eliseu Martins em sua Tese de Doutorado sobre a Avaliação do Ativo Intangível 36 anos depois.

Desejo a todos uma excelente leitura, ao mesmo tempo em que reforço o convite para que submetam seus artigos científicos para a REPeC.

Prof. Dr. José Francisco Ribeiro Filho

Editor Científico. 